Volume and Issues Obtainable at Center for Sustainability Research and Consultancy

Journal of Accounting and Finance in Emerging Economies

ISSN: 2519-0318 ISSN (E) 2518-8488

Volume 3: Issue 1 June 2017

Journal homepage: www.publishing.globalcsrc.org/jafee

\title{
Industry Leaders not responding to Global Financial Crises
}

\author{
${ }^{1}$ Rahat Sabah
}

${ }^{1}$ MPhil Commerce, Bahauddin Zakariya University, Multan, Pakistanrahatsabah@gmail.com

\begin{tabular}{|c|c|}
\hline ARTICLEDETAILS & \multirow{8}{*}{$\begin{array}{l}\text { Purpose: The purpose of my study is to attract the attention of the industry } \\
\text { leaders and make them realize that, why they are not using their abilities of } \\
\text { quickly recognizing and picking the new/wining ideas to control and } \\
\text { discontinue the global financial crises. The basic idea behind the study is to } \\
\text { bring Industry Leaders on a board to build a link of International Forums to } \\
\text { make long term global financial goals and policies to improve the Global } \\
\text { Financial System. No doubt the business world is more complicated than } \\
\text { previous generation and financial crises bring real danger and affecting } \\
\text { almost everyone in an increasingly inter-connected world but it does not } \\
\text { mean that our industry leaders are not able to meet it and defeat it. }\end{array}$} \\
\hline History & \\
\hline Revised format: May 2017 & \\
\hline AvailableOnline: June 2017 & \\
\hline Keywords & \\
\hline Crises, & \\
\hline Industry & \\
\hline $\begin{array}{l}\text { JEL Classification: } \\
L 7, Q 02\end{array}$ & \\
\hline
\end{tabular}

(C) 2017 The authors, under a Creative Commons Attribution-

NonCommercial 4.0

Corresponding author's email address: rahatsabah@gmail.com

Recommended citation:Sabah,R., (2017).Industry Leaders not responding to Global Financial Crises.Journal of Accounting and Finance in Emerging Economies, 3(1) 55-62.DOI:https://doi.org/10.26710/jafee.v3i1.81

\section{Introduction}

I began my research by identifying the effects of financial crises and this struck me that financial failure not only disturb and bring economic difficulties for consumer, producer, banking business, insurance companies and capital market but also produce the social unrest, hunger, insecurity, job loss, stress, and corruption, fraud, cheating, and stealing. Then two questions arouse in my mind that who will discontinue and control the financial crises and how? Who will help the investors to save their money against the risk and manage the business world and how? I studied and handled a number of Articles, Business Recorder, Financial Time Newspapers, Books, Speeches, Global Financial Stability Reports and Journals reviewed by Academy of Management and I received a lot of journals from different subscriptions throughout my period of research since 2013. Each of my research related material is very inspiring and important and give me the answer of part one of both questions, that is the industry leaders will discontinue and control the global financial crises and manage the business world but I was unable to find the answer of How?.So I set out my study into two parts. The first part focused on the effects of global financial crises and the key role of industry leaders in making the long term global financial goals and polices. In the first part I have drawn attention on the reasons due to which Industry Leaders cannot use their abilities properly to quickly recognize and picking the new/winning ideas like the Walt Disney, Bill Gate, Henry Ford, Pay Kroc who have changed the face of Industry and made an impact on business world, and the contribution of Frederick Winslow Taylor, Peter Ferdinand Drucker, in philosophical and practical foundations of the modern business corporation. I have also quoted the example of Japan and pointed out that how it become a developed nation and be recognized as a social and economic superpower, not only in its region, but on a world scale. The second part of investigation is focused on how to bring the industry leaders on a board to build a systematic link of International Forum to discontinue and control the 
financial crises and remove the critical weaknesses here in the global financial system to manage the business world and leads the business community.

Effects of Global Financial crisis. The global financial crises have led to economic crises which have led to human rights crises, (Anup Shah,2013)The International Labor Organization estimates that world-wide unemployment could rise by at least 30 million people, and possibly as much as 50 million people, from 2007 to 2009, if conditions continue to deteriorate. It also expects that more than 200 million people, mostly in developing economies, will be pushed into poverty (Recommendations of the UN Commission of Experts, 2009). During my exploration I measured that it doesn't matter who is responsible for the global financial crises but, it does matter who is effecting from the global financial crises and this is more important is to bring them out from the crises. When the sign of crises is shown, it is not just the wealthy that suffer, but potentially everyone. When stock market falls and large financial institutions collapse then it affects the performance of all other Government and Non-Government Institutions and overall performance of the country is low down. When the position of a country is near to the ground then it affect the livelihoods of almost everyone in the country/region.

\section{What Industry Leaders Do?}

Let's talk about the world today. Mr. Jose Escamilla, ended his speech with a few figures that his daughter had sent him. Eight out of ten people living in the world today live in sub-standard housing. Seven in ten cannot read. Five in ten do not eat enough. And one in a hundred has a college degree. That's the world we live in. These figures are important because it shows there are many people who need to improve their living standards. At the same time there is a great need for entry level jobs in industry. What kinds of work will the world do; what industries will thrive, how we the people can improve our lives (Robert C. Haywood, 2004). During my study I have found that if the business world would be better and developed then there is no doubt this improvement will lead to improve the lives of people in the world. And this improvement will only come from the side of industry Leaders. While during the financial crises and recession the investors have lost their confident level to take risk in investment therefore it is needed to restore their confident by creating a systematic link among International Corporate Directors, World Export Processing Zones Association, International Chamber of Commerce \& Industry and International Business Scholars so that they can explore new market opportunities and pick new ideas to manage the business world and help the business community to the right direction, to manage risk during the recession and to save money during the global financial crises.

Figure.1

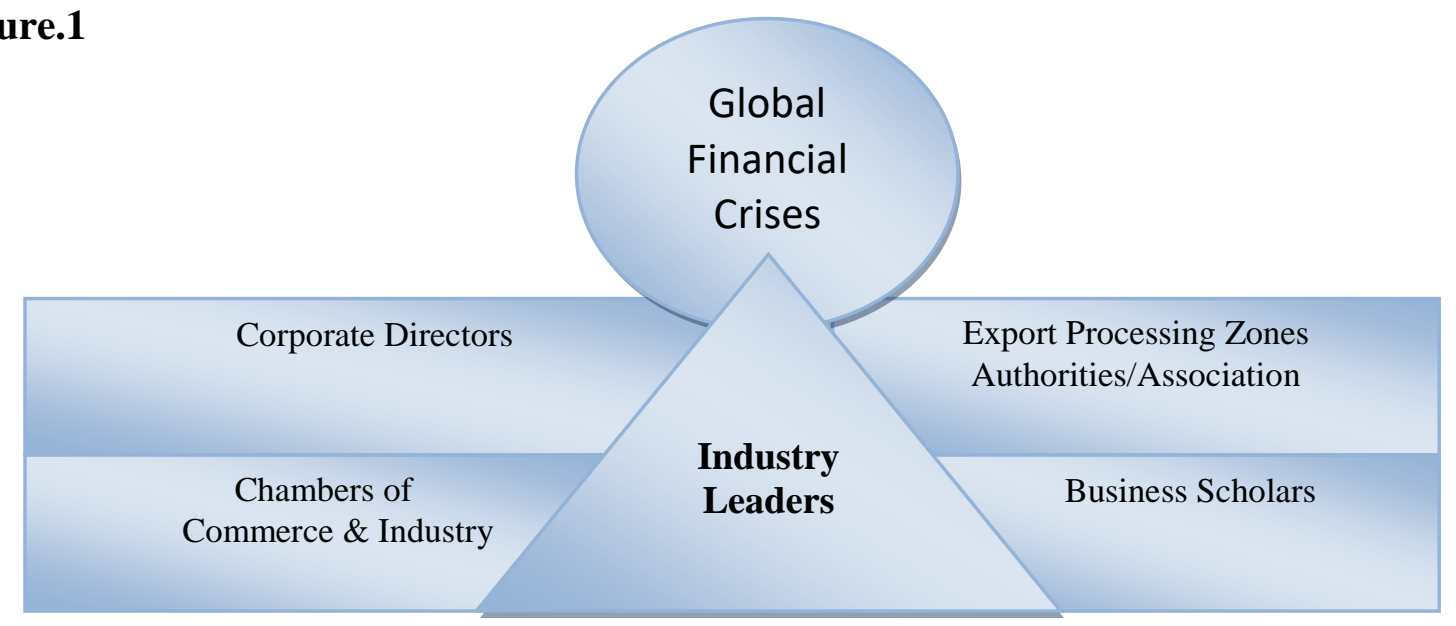

\subsection{Corporate Directors}

The financial services industry has claimed an ever-growing share of the nation's income over the past generation, making the people who run the industry incredibly rich. The vast riches achieved by those who managed other people money have had a corrupting effect on our society as a whole (Paul 
Krugman, 2008). As our world is becoming global the organizations are transferring from national to international domain so that the responsibilities and functions of our corporate directors have also become wide and remain not limited to their own region. The globalization also brings more opportunities with challenges so International Corporate Directors need more knowledge, long term strategic planning and ability to recognize and picking the new/wining ides to response any types of challenges and crises. The history shows that those who come up with new ideas, initiatives and spirit of moving the organizational mission forward can change the face and dynamics of industry and business world. The Microsoft achieved prominent position and reputation in the world due to the management style and strong work ethics of Bill Gates. His first responsibility for the company was product development strategy; he has divided his responsibilities in two paths in day to day management and long-term product strategies. Walt Disney kept engaged his employees towards improvement and new ideas. Walt found a way to push improvement without laying blame, he demand a positive, forward-thinking attitude "what we can do to make it better" (Robert Niles 2009). Henry Ford was an innovator and industrialist who turned his mechanical into a global company that transferred life around the world. He is a man of many interests and had a highly developed sense of curiosity, he never stopped exploring new fields and learning about new subjects. Henery Ford was successful where others had failed. Henery Ford's motto of "help the other Fellow" spilled over into his management style; he recognized that policies generous to his employees would result in happier workers and a better product. He claimed, however, not to believe in conventional charity; rather to provide opportunities for people to help themselves (Walter Elias Disney, 2008).

\subsection{Business Scholars}

The term Enterprises Resources Planning (ERM), Business Process Re-engineering (BPR),Total Quality Management (TQM) and Human Resources Management (HRM) where they come from. These are the business scholars who changed the face of business world and industry. Peter F Drucker is a writer, teacher, and consultant specializing in strategy and policy for business and social sectors organizations. For nearly 60 years now, he has been one of the most influential thinkers and writers about management. He has consulted with many of the world's largest corporations as well as with nonprofit organizations, small and entrepreneurial companies, and with agencies of US government (Shaker A. Zahra, 2003). Frederick Winslow Taylor, originator of the modern scientific management movement, the writings and lectures of Frederic Winslow Taylor formed the basis of the recent reorganization of methods of handling labor in many of the largest industries in the country (New York Times, 1915). The Fredrick Winslow Taylor is not quite dead born more than one hundred years ago (1856), departed for more than two-score years (1915), and father of scientific management for over three-quarters of century (The journal of the academy of management). The economic rehabilitation of Japan is closely tied in with the efficient use of her domestic resources. Early in the Occupation, surveys in the fields of mining and geology, agriculture, fisheries, and forestry revealed the extent to which utilization of Japan's meager natural resources had been dislocated by the war. They pointed up the urgent need for emergency measures and for basic long-range reforms (Major General Paul J.Mueller,2007). "In fact the whole of Japan is a pure invention," Oscar Wilde wrote in 1889. "There is no such country, there are no such people (Patrick Smith \& Alfred A. Knopf).

\subsection{Chamber of Commerce\&Industries}

The first chamber of commerce was founded in 1599 in Marseille, France. It is considered a community work on local level to bring the business community together to develop a strong local network for business to business exchange. Chamber of commerce can be local, city, community; regional and chamber of society. It is a form of business network, a local organization of business or a board of trade engaged to increase the interests of businesses. It is not a governmental organization. Local businesses are its members and they elect a board of directors or executive council to set policy for the chamber. State Chambers work with their Governor and are looked to as a respected voice, representing the entire business community to enhance and advocate for a better business environment. The International Chamber of Commerce or American Chamber of Commerce is largest business 
network globally. Because this network is informal, with each local chamber incorporated and operating separately, rather than as a chapter of a national or state. While all networks of chambers, are working separately. They have neither registered membership of International Chambers of Commerce nor have any systematic link with other business network formally as well as with the other industry leaders to make direct rules and regulations that effect business; therefore they could not response the global financial crises.

\subsection{Exports Processing Zones}

The Export Processing Zones (EPZ) is actually a type of Free Trade Zone which was established in, Ireland to promote employment within a rural area, make use of regional airport and generate revenue for the Ireland economy to decrease poverty. In some countries the EPZ is called Special Economic Zones. While the purpose of EPZ is increase foreign earning by promoting export, by creating link between the EPZ and respective country and by transfer of technology, therefore it is considered the tool for development for the country. EPZ /FTZ is also called foreign trade zones and free port is an area where goods are handled, landed, manufactured and export. These Zones are established in export potential areas around the sea port, major airports or areas which have geographical advantage for trade and export. World Export Processing Zones Association (WEPZA) is the private non-profit World Association of Economic Processing Zones and Free Trade Zones. It is also an independent association dedicated to the improvement of the efficiency of all Economic Processing Zones (EPZs). This is created to support the needs of a specific industry such as banking, jewelry, oil and gas, electronics, textiles, tourism, etc. Companies invested in the zone may be located anywhere and receive benefits. It supplies newsletters, a database, training seminars and supporting conferences and workshops around the world. EPZs are very important players in the changing world and leading many countries into globalizations.

\section{Suggestions}

The second part of both questions however more difficult to answer .it went something like this "how to bring the industry leaders on board to create a systematic link among them to response the global financial crises. So I begin my work to find out the answer because, I was very confident that our industry leaders have the abilities to response the global financial crises if they think and work beyond the geographical boundaries and keep them isolate from international politics. I would rather suggest our business leaders to come on board and join in an international forum towards the resolution of problems being faced by the business world. It will be possible in three steps as illustrate in Figure 2,3,4\&5 below. All the 196 countries in the world should be called by the industry leaders to set up these four associations as:

\section{Step 1.}

\section{Figure 2}

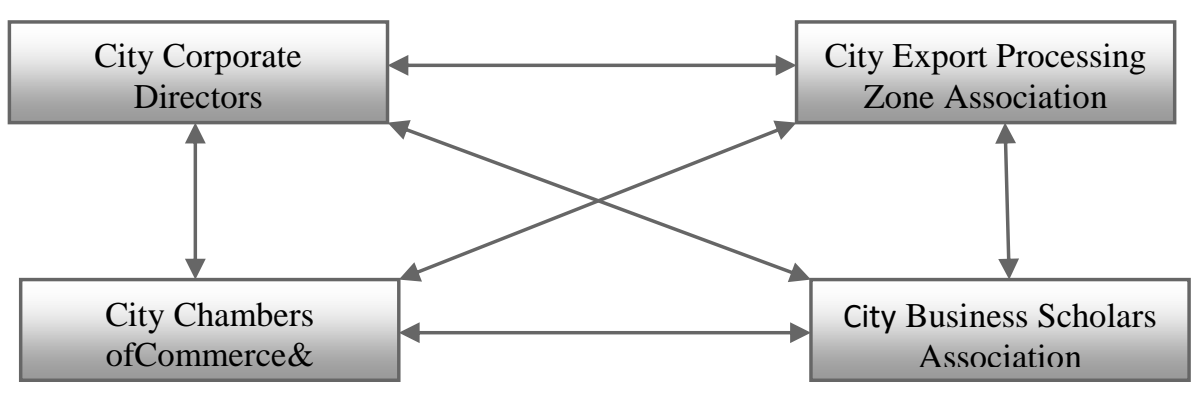

This will start first from local level. All city/local Chambers of Commerce \& Industries, city/local Corporate Directors, Export Processing Zones and city Business Scholars should make their own associations and create systematic link among each other as shown in figure above. If City Chamber of 
Industry have one hundred registered members it must hire two business scholars as consultant from city Business Scholar Association and make public private partnership with any five corporations handled by City Corporate Directors Associations under the roof of Export Processing Zones Authority. A meeting would be held of President /CEO of four associates at the end of the each month where they share information and set long term goals and policies for local business and development projects. Every President /CEO of every local association would be the registered member of his/ her respective National Association from every city. In this way the national associations will come into being as have shown in figure 3 .

\section{Figure 3}

Step 2.

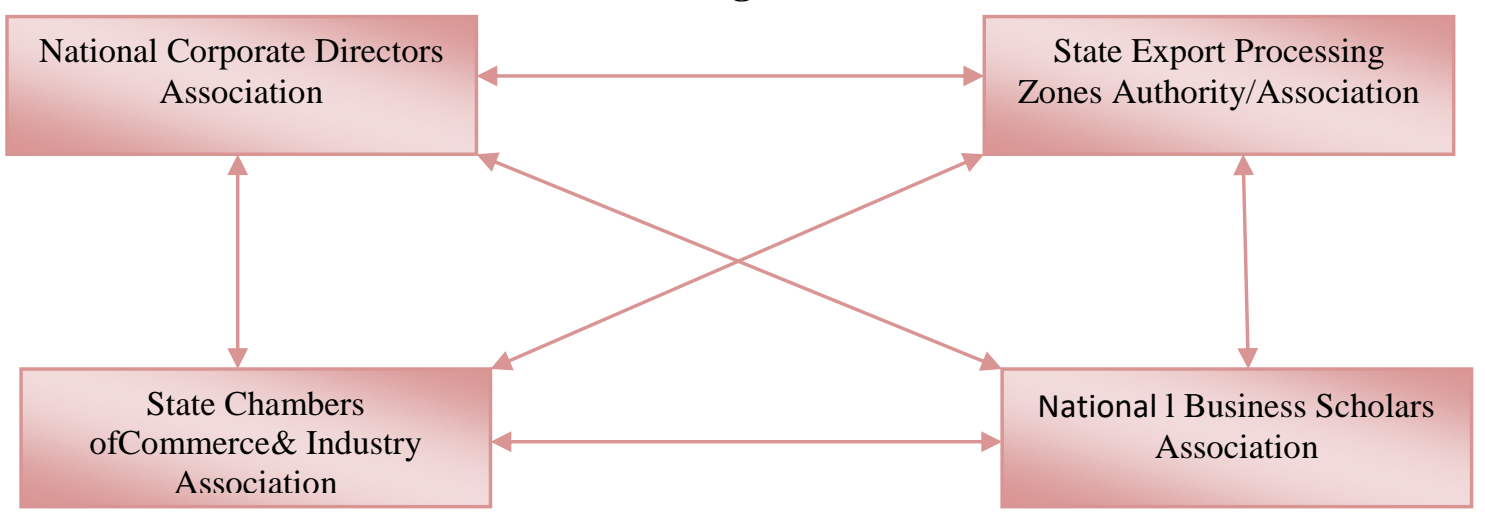

When these above four national associations would be consists on local presidents/CEO from all city associations consequently the national associations not only become aware about the position and condition of local markets and industry but also the explore the opportunities and potential areas for exports for the progress of the country as well. In the same method these four national associations then will make then International associations as shown in figure.4.

Step 3.

Figure 4

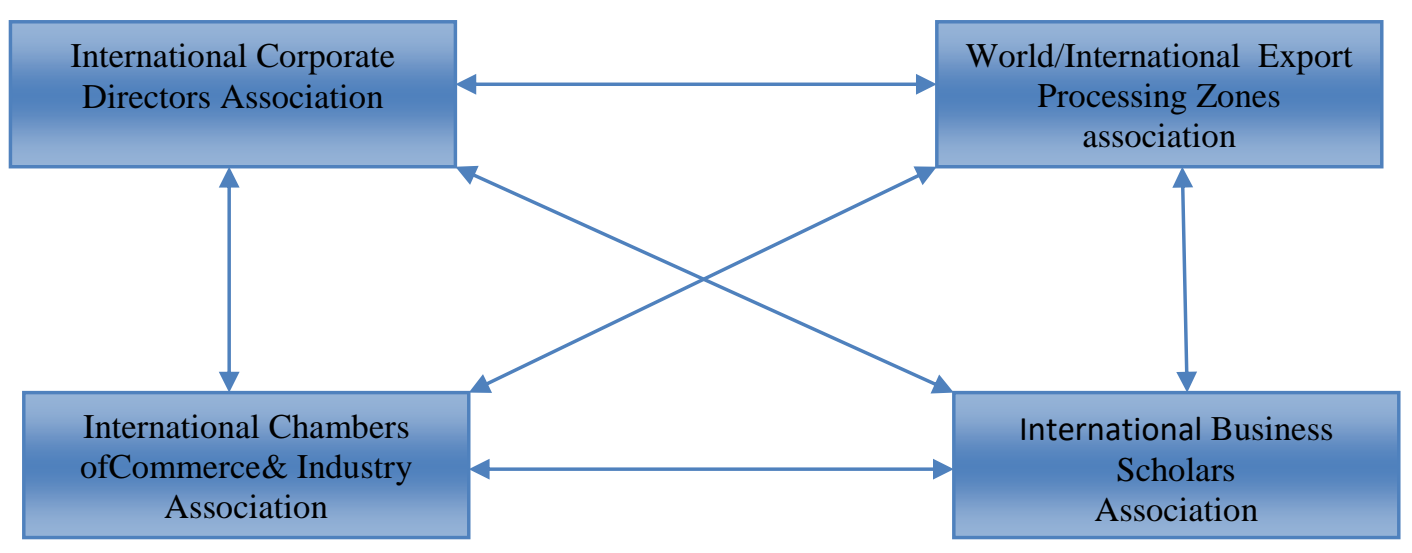

In step 3 the international associations will came into existence. All CEO /Presidents of a national association's will be the member of International associations. In this way systematic link would be created among the industry leaders from local to national and national international associations. As shown in figure 5. 
Step 4

Figure 5.

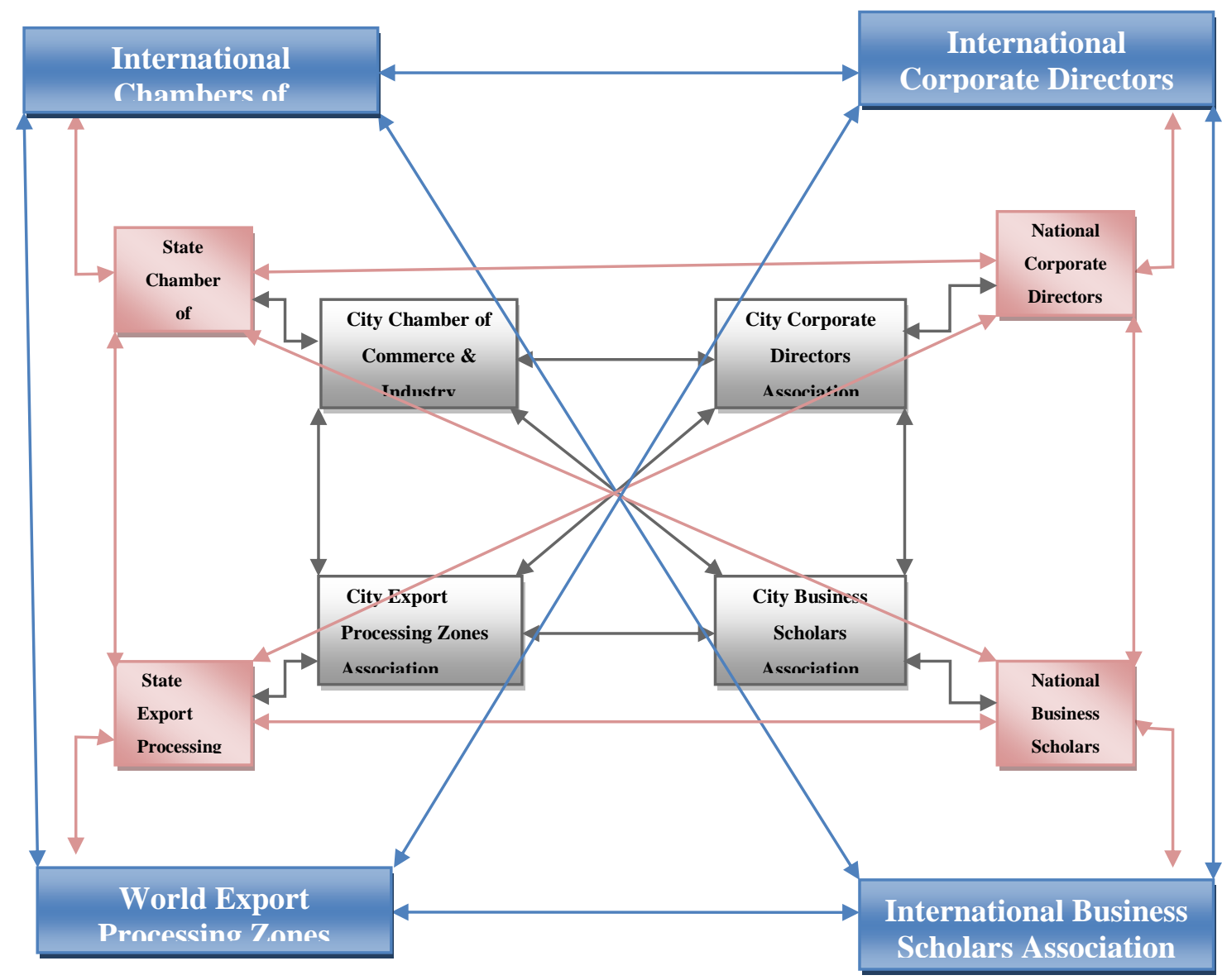

When the Industry would make long term Global financial policies according to the investment trend, financial system and current market condition of every country then there would be no country left poor, because in this way the Industry Leaders would have the information about the market condition, financial system, opportunities, potential areas for export of any member country's national level as well as at its own local/city level.

\section{References}

Alfred Bornemann, 1961.The Development of the Teaching of Management in the School of Business Academy of Management Journal, Vol. 4, No. 2. pp. 129-136. Arvid O. I. Hoffmann, Thomas Post \&Joost M. E. Pennings, 2011.Maastricht University, WageningenUniversity, and University of Illinois at Urbana-Champaign. Individual Investors and the Financial Crisis:

Amnesty International, 2009.A Report highlights the impact of economic crisis on human rightsacrossThe world, updated by Anup Shah, 2013.

J. Boddewyn, 1961.Frederick Winslow Taylor Revisited, Academy of Management Journal, Vol. 4,No. 2, pp. 100-107.

1J.Mueller, 2007. Occupied Japan, A progress report.

F. W. Taylor, Expert in Efficiency, Dies by the New York Times .

Patrick Smith Alfred A. Knopf .Japan A Reinterpretation.EBook.Part I, among themselves The Invisible Japanese.

Recommendations of the UN Commission of Experts on Reforms of the International Monetary andFinancial System, 19 March 2009, p. 2.Note by President. 
Sophia n. Antonopoulou, 2010.the Global Financial Crisis, the Global Financial Crisis.The International Journal of Inclusive Democracy, Vol. 6, No. 1 .

Walter Elias Disney, 2008, Founder of Walt Disney Co.Founded: 1923 "If you can dream it, you can do it. 
